\title{
Perspectives for rare earth elements as feed additive in livestock - A review
}

\author{
Hujaz Tariq ${ }^{1, *}$, Amit Sharma ${ }^{2}$, Srobana Sarkar ${ }^{3}$, Lamella Ojha ${ }^{1}$, Ravi Prakash Pal', and Veena Mani ${ }^{1}$
}

* Corresponding Author: Hujaz Tariq Tel: +91-9896492089, Fax: +91-184-2250042,

E-mail: hujaztak@gmail.com

'Animal Nutrition Division, ICAR-National Dairy Research Institute (Deemed University), Karnal, Haryana 132001, India

2 Department of Animal Nutrition, Guru Angad Dev

Veterinary and Animal Sciences University, Ludhiana,

Punjab, 141004, India

${ }^{3}$ ICAR- Central Sheep and Wool Research Institute,

Avikanagar, Rajasthan, 304501, India

ORCID

Hujaz Tariq

https://orcid.org/0000-0002-3568-118X Amit Sharma

https://orcid.org/0000-0003-3241-661X

Srobana Sarkar

https://orcid.org/0000-0002-3282-814X

Lamella Ojha

https://orcid.org/0000-0002-1524-7175

Ravi Prakash Pal

https://orcid.org/0000-0002-4848-6965

Veena Mani

https://orcid.org/0000-0002-7719-8460

Submitted Mar 22, 2019; Revised May 15, 2019; Accepted Jun 30, 2019

\begin{abstract}
There is a need for newer feed additives due to legal prohibition on inclusion of growth promoting antibiotics in livestock diets in several countries due to antimicrobial resistance. In this context, rare earth elements (REE) have gained attention among animal nutritionists as potential growth promoters. Currently, several studies have reported better weight gain, milk production, egg laying capacity and feed conversion efficiency among different breeds of farm animals following supplementation with REE, with however largely inconsistent results. Furthermore, REE supplementation has also shown to improve ruminal fibrolytic and proteolytic activities as well as flavor of meat with negligible residues in edible tissue, however the mechanism behind this action is still unclear. According to existing research, due to their poor absorption and similarity with calcium REE might exert their action locally on gut microbial populations within the gastrointestinal tract (GIT). Moreover, REE have also shown anti-inflammatory, anti-oxidative as well as immune stimulating effects. The present review aims to broaden the knowledge about use of REE as feed additives for livestock and sum up efficacy of REE supplementation on performance and health of animals by comparing the findings. Till date, researches with REE have shown properties that make them a promising, new and safe alternative feed additive but further exploration is recommended to optimize effects and clarify discrepancy of various results before practical proposals can be drafted.
\end{abstract}

Keywords: Antimicrobial Resistance; Livestock Production; Rare Earth Elements

\section{INTRODUCTION}

Feed additives are ingredients/chemical compounds or combinations thereof which are added to the basal ration to fulfill specific requirement or to improve weight gain, feed efficiency and control diseases in farm animals. Feed additives can be broadly classified into nutrient (amino acids, minerals, and vitamins) and non nutrient (antibiotics, hormones, enzymes, prebiotics, yeast culture, pellet binder, antioxidants etc.) feed additive [1]. Antimicrobial compounds such as antibiotics were previously used in feeds for therapeutic purposes to cure and prevent infectious diseases. But soon the growth promoting effect of antibiotics came into limelight under intensive animal rearing system; thereafter these were added at sub therapeutic doses to animal feeds as an additive for nearly 6 decades. These compounds also improved feed utilization (2\% to $5 \%$ ) and reduced morbidity as well as mortality due to clinical and subclinical diseases [2,3]. However, extensive use of antibiotics at therapeutic or subtherapeutic doses over long period of time provides favorable conditions for proliferation of antimicrobial resistant microorganisms in animals, plants and soil [1].

At present global concern regarding antimicrobial resistance and transference of resistant strains gene from animal to human is rising [4-6]. Therefore, the potential risks associated 
with development of antibiotic resistant bacteria and its transmission led to the ban on use of feed antibiotics as growth promoters in European Union since 2006. This ban endorsed scientific community and animal feed industry to actively explore alternatives for feed antibiotics which could improve feed efficiency, weight gain and manipulate rumen fermentation [7]. As a result, the rare earth elements (REE) have gained interest among animal nutrition research for its efficacy as a feed additive in substitution to antibiotics.

The REE are not a newer feed additive as these have been successfully used as fertilisers in plant production and as growth promoter in animal production for many decades in China [8]. Till date numerous scientific reports indicated that a small amount of REE mixtures in the diet of farm animals increased live weight gain, feed efficiency and milk/egg production $[9,10]$. The REE are naturally occurs in the environment and consist of three members of group IIIB, namely scandium (Sc; atomic number 21), yttrium (Y; atomic number 39), lanthanum (La; atomic number 57) and 14 chemical elements from group IIIA of the periodic table called lanthanoids (atomic numbers 58-71) viz. cerium (Ce), praseodymium $(\mathrm{Pr})$, neodymium $(\mathrm{Nd})$, promethium $(\mathrm{Pm})$, samarium $(\mathrm{Sm})$, europium $(\mathrm{Eu})$, gadolinium $(\mathrm{Gd})$, terbium $(\mathrm{Tb})$, dysprosium (Dy), holmium (Ho), erbium (Er), thulium (Tm), ytterbium $(\mathrm{Yb})$, lutetium $(\mathrm{Lu})$, and the elements $\mathrm{Y}$ and Sc. These are frequently divided into two subgroups: the light or Ce group and the heavy or $\mathrm{Y}$ group. The Ce group consists of the elements $\mathrm{La}, \mathrm{Ce}, \mathrm{Pr}, \mathrm{Nd}, \mathrm{Pm}, \mathrm{Sm}$, and $\mathrm{Eu}$, whereas $\mathrm{Y}$ group comprises the elements Gd, Tb, Dy, Ho, Er, Tm, Yb, Lu, and $Y$ [11]. The importance of various inorganic elements (commonly known as minerals) in human, animal and plant nutrition are very familiar and are required for various metabolic functions [12-14]. Now, among inorganic elements, REE emerges as new generation growth promoter feed additive alternative to feed antibiotics for livestock. The aim of present review is to broaden the knowledge about use of REE as feed additive in livestock, its effect on health and performance of animals as well as its accumulation in animal tissue.

\section{HISTORICAL ASPECTS RELATED TO RARE EARTH ELEMENTS}

The history of the discovery of REE is very old and first element to be discovered was in 1788, by the Swedish army lieutenant Karl Axel Arrhenius, who collected the black mineral ytterbite (named after the nearby Swedish town). After that, Gadolin in 1794, isolated ytterbia from the mineral ytterbite using fractional crystallization and explained their chemical properties. This created the interest among many scientists and with development of various technology like spectroscopic methods of analysis and the exploration of electrochemical separation led to discovery of various REE. The latest REE discovered was Pm in 1947 through the use of ion exchange chromatography from fission fragments of uranium.

\section{OCCURRENCE, MINERAL SOURCES, AND SEPARATION TECHNIQUE}

The term "rare earths" is a misnomer as these elements are neither rare nor earths. The word "rare", relates to the considerable difficulties in separating one REE from another because of their close similarity in physical and chemical properties. All REE are more common than $\mathrm{Ag}$ or $\mathrm{Hg}$ [11] and $\mathrm{Tm}$, the rarest of the REE, are found more often than gold, platinum or iodine [15]. The term "earths" was used in the 18th century for describing alkaline metal oxides, as they were first identified as rare earth oxides. Rare earth elements are widely distributed and mainly occur as phosphates because they have strong affinity for phosphate. Moreover, oxides, silicates, carbonate and halogen compounds of REE are also present in mineral deposits under natural conditions [16]. There are more than two hundred mineral deposits known to contain REE and among which few of them are useful for industrial production.

Several methods of separating rare earths have been identified, but none are considered to be universal. Usually there are choices between either acidic (using sulphuric acid) or alkaline (using caustic soda) methods of breakdown, which are temperature dependent. High purity isolates for commercial purposes are mainly obtained by solvent extraction while ion exchange resins are used in special cases [15].

\section{MECHANISM OF ACTION AND BIOLOGICAL EFFECTS OF RARE EARTH ELEMENTS}

The scientific literature and evidences on the mechanism of REE which enhances the performance of animals are limited and not well established. However, various biological effects based on results of different feeding trials on supplementation of REE in the diet of animals have been proposed (Figure 1) viz. antibacterial property, antioxidant nature, increased hormonal, and enzyme activities, proliferation of specific cells, stimulation of immune system, enhancement of digestibility and nutrient utilization $[10,17]$. These effects of REE can be either due to their similarity with calcium (radius of $\mathrm{Ca}$ is very close to lanthanoids) or poor absorption from the gastrointestinal tract (GIT) $[18,19]$. Moreover, it is believed that the little amount of absorbed REE affected various physiological process like hormonal concentration, enzyme activity, activation of immune system, metabolism of nutrients (protein or lipids) and cell proliferation [20,21]. Further, REE are supposed to have hormetic effect on microbes i.e. concen- 


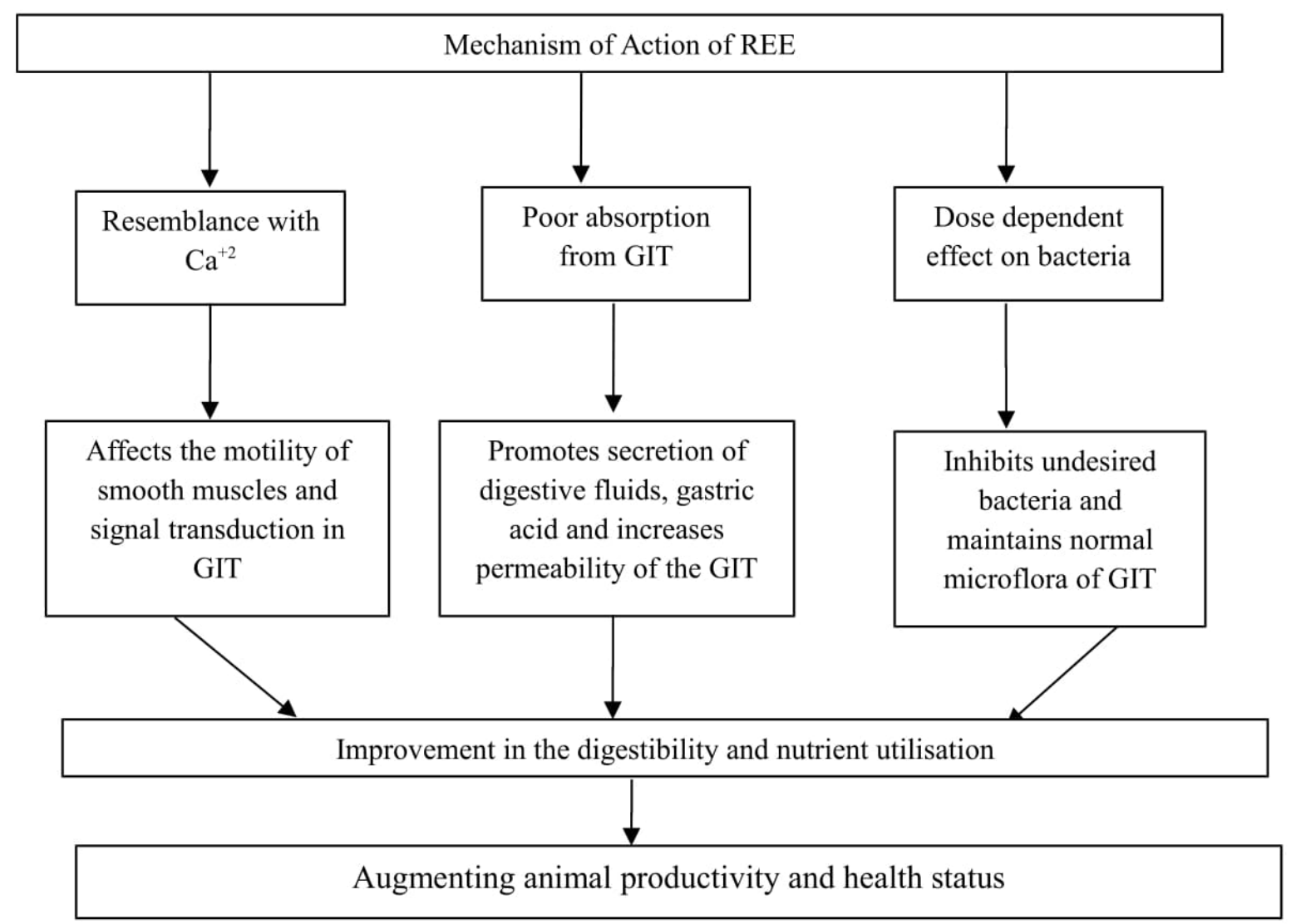

Figure 1. Proposed mechanism of action of rare earth element. REE, rare earth elements; GIT, gastrointestinal tract.

tration-related effects, by improvements in biological events at low levels, followed by inhibitory effects at increasing concentrations [22-24].

Interaction with intermediate metabolism and antibacterial properties of rare earth elements Muroma [25], first observed the antibacterial effect of REE and reported its dose dependent activity i.e. at higher concentrations $\left(10^{-4}\right.$ to $\left.10^{-2} \mathrm{~mol} / \mathrm{L}\right)$ these elements inhibit bacterial growth mainly Gram negative, whereas at lower concentrations $\left(10^{-5} \mathrm{~mol} / \mathrm{L}\right)$ bacterial growth was stimulated. Similarly, Zhang et al [26] concluded that the growth of Escherichia coli (E. coli), Bacillus pyocyaneus, Staphyloccous aureus, Leuconostoc, and Streptococcus faecalis were inhibited by $\mathrm{Ce}\left(10^{-3} \mathrm{~mol} / \mathrm{L}\right.$ to $\left.10^{-2} \mathrm{~mol} / \mathrm{L}\right)$. Zhao et al [27] also reported that Ce ions at concentrations below $350 \mu \mathrm{g} / \mathrm{mL}$ had a stimulatory effect on the growth of E. coli, whereas concentrations at or above 400 $\mu \mathrm{g} / \mathrm{mL}$ had an inhibitory effect. Stimulatory effect of REE was explained by Talburt and Johnson [28] as they reported that oxalic acid produced by Aspergillus niger combines with REE to form insoluble oxalates and resulting in detoxification mechanism permitting further growth of this microbes. More recently, Liu et al [29] explained inhibitory of REE using La nitrate effect on the growth of $E$. coli B. They observed that there was an abnormal "eruption of heat" phenomenon at high concentration $(500 \mathrm{mg} / \mathrm{L})$ led to damage the outer cell membrane and increases its permeability along with reduced proton-electron potential energy across the cell membrane. Further, the growth of the cells was inhibited due to scarceness of energy adenosine triphosphate (ATP) as energy could not be translated into ATP effectively in the course of oxidative phosphorylation and resulted in more heat release. Therefore, from above studies it can be considered that REE has hormetic properties so use of REE in feed might enhance animal performance by influencing the development of desired bacterial species within the GIT selectively in a dose dependent manner.

Improvement of digestibility and nutrient utilization In case of rats absorption of REE from GIT was reported to be less than $0.01 \%$ [30], while, absorption factors for chickens ranged from $10^{-3}$ to $10^{-4}$ [31]. Hence, orally supplemented REE generally accumulates within the GIT and promotes the secretion of digestive fluids and influences the permeability of intestine, thereby enhancing the absorption of nutrients as well as digestibility [32-34]. Further, these elements show resemblance with $\mathrm{Ca}$, not only in size and bonding but also in coordination geometry and donor atom preference. So, 
these elements may affect the $\mathrm{Ca}^{2+}$-dependent release of chemical mediators [18]. Further, REE interact with biomolecules by binding to $\mathrm{Ca}^{2+}$ or $\mathrm{Mg}^{2+}$ binding sites of calmodulin, ATPase of sarcoplasmic reticulum, cystatin and phosphatidylserine. The binding mode of various REE to calmodulin is varied a lot as $\mathrm{Lu}^{3+}$ and $\mathrm{Er}^{3+}$ bind like $\mathrm{Ca}^{2+}, \mathrm{Eu}^{3+}$, and $\mathrm{Tb}^{3+}$ binding the opposite order from $\mathrm{Ca}^{2+}$, whereas, $\mathrm{La}^{3+}$ and $\mathrm{Nd}^{3+}$ binding a mode between them [18]. On the other hand, the poor absorption of REE is supposed to be associated with its accumulation in GIT which further affects the growth of harmful bacteria resulting in anti-bacterial, anti-inflammatory effects as well as increased digestibility of nutrients in the GIT. These mechanisms show that REE can stimulate the digestive micro-organisms or enzymes and increase ruminal fibrolytic well and proteolytic activities. Moreover, the palatability of diet remains unaffected as these elements are generally tasteless in nature. Hence, beneficial properties of REE supplementation in the diet of animals may be through its effect on feed intake, passage rate and nutrient digestibility $[30,10]$. The pathways through which these absorbed REE acts on physiological processes remains indistinct, so the essentiality and physiological roles of REE in animals and human beings are inconclusive.

\section{ROLE OF RARE EARTH ELEMENTS IN ANIMAL HUSBANDRY}

Supplementation of animal feeds with REE has been practiced in China for many decades. After the ban on antibiotic growth promoters, these elements have come into focus as newer natural feed additives in substitution to antimicrobials. Numerous studies reported that certain dose of REE in the diet of animals could improve their health, body weight (BW) gain, feed conversion efficiency, milk and egg production $[9,35]$.

\section{Non ruminants}

Pig: In case of pig promising growth promoting effects of REE were observed. It was reported that supplementation of a mixture of REE $\left(38 \% \mathrm{LaCl}_{3} \cdot 6 \mathrm{H}_{2} \mathrm{O}, 52.1 \% \mathrm{CeCl}_{3} \cdot 6 \mathrm{H}_{2} \mathrm{O}, 3 \%\right.$ $\mathrm{PrCl}_{3} \cdot 6 \mathrm{H}_{2} \mathrm{O}$, and $6.9 \%$ chlorides of other REE) at a dose of $300 \mathrm{mg} / \mathrm{kg}$ of feed resulted in higher BW gain (19\% and 12\%) and feed conversion ratio (FCR) (11\% and 3\%) in growing and fattening pigs respectively. Moreover, it was observed that supplementation of REE for 3 months had no residual effect in the muscle, liver and kidneys of pigs [21]. In this context, apart from REE mixture individual supplementation of La at a dose of $100 \mathrm{mg} / \mathrm{kg}$ dry matter (DM) in diet increased average daily gain (ADG) and FCR by $12.95 \%$ and $6.78 \%$ respectively [9]. Further, in the above study it was also reported that La residues in selected organs (longissimus muscle, liver, kidney, and pancreas) remained unaltered with supplementation of dietary La. The non-residual effect of REEs in tissues may be due to poor absorption or rapid elimination of REEs from the body of animals. Hence, health of the animals and safety of animal products are not influenced by supplementation of REE mixture or La in the diet of pigs. Recently, organic form of REE i.e. REE-enriched yeast (RY; containing 2.82\% La, $4.71 \% \mathrm{Ce}, 40.3 \%$ distillers dried grains with solubles (DDGS) and 52.17\% yeast) was studied for its effect on feed intake and animal performance in comparison to supplementation of tiamulin antibiotic in the diet of finishing pigs [36]. Animals in control group were fed on only basal diet, whereas in RY groups, they were supplemented with graded levels i.e. 500, 1,000, and 1,500 ppm RY and in antibiotic group tiamulin $500 \mathrm{mg} / \mathrm{kg}$ was added in the feed along with basal diet. It was observed that ADG, average daily feed intake, gain to feed ratio, apparent total tract digestibility of DM and gross energy were enhanced linearly with graded levels of RY as compared to control group only. The performance of pig supplemented with RY remained at par to pigs supplemented with antibiotics tiamulin. Therefore, REE could be considered as a possible effective and safe substitute to feed antibiotics. The improved performance of pigs supplemented with REE may be related to its antibacterial properties. Although, Kraatz et al [37] observed that addition of REEcitrate (a premix containing predominantly organic citrate compounds of $23.3 \% \mathrm{La}, 68.2 \% \mathrm{Ce}, 8.0 \% \mathrm{Pr}$, and $0.4 \% \mathrm{Nd}$ ) at $200 \mathrm{mg} / \mathrm{kg} \mathrm{DM}$ in the diet of weaning piglets had no significant effect on FCR and fecal microbiota. Similarly, Halle et al [38] also reported non-significant effect of REE supplementation on nutrient digestibility in pigs. The variations in the results of different studies may be endorsed to the dose of REEs along with the type used for supplementation in different trials. Various other studies regarding the effect of REE on swine production and health have been highlighted in Table 1.

Poultry: Effect of REE supplementation in poultry diets have been summarized in Table 2. Addition of REE to layer diets (30 to $1,000 \mathrm{mg} / \mathrm{kg}$ feed) resulted in increased egg production (3\% to $15 \%$ ), hatchability (5\% to $15 \%$ ) and improved feed conversion efficiency (2\% to $22 \%$ ) as well as BW gain (4\% to $14 \%)[39,40]$. Recently, Cai et al [41] observed that supplementation of RY at $1,500 \mathrm{mg} / \mathrm{kg}$ (containing $42.3 \mathrm{mg} / \mathrm{kg}$ $\mathrm{La}$, and $70.65 \mathrm{mg} / \mathrm{kg} \mathrm{Ce}$ ) during starter and growing period resulted in improved nutrient digestibility and meat quality. However, there was no significant influence on growth performance, relative organ weight and excreta microflora. Earlier He et al [42] compared the effect of dose and form of REE compounds i.e. organic and inorganic REE supplementation on broiler performance. They supplemented REE-chloride (containing $\mathrm{LaCl}_{3} 380 \mathrm{mg} / \mathrm{kg} ; \mathrm{CeCl}_{3} 520 \mathrm{mg} / \mathrm{kg} ; \mathrm{PrCl}_{3} 30$ $\mathrm{mg} / \mathrm{kg}$, and chlorides of other REE $70 \mathrm{mg} / \mathrm{kg}$ ) at $40 \mathrm{mg} / \mathrm{kg}$ and REE-citrate (La-citrate, $210 \mathrm{~g} / \mathrm{kg}$; Ce-citrate $670 \mathrm{~g} / \mathrm{kg}$; 
Table 1. Literature summary of effect of REE supplementation in pigs

\begin{tabular}{|c|c|c|}
\hline Dose & Results and conclusions & Reference \\
\hline 100 mg/kg DM La for 30 days & $\begin{array}{l}\text { - Significant increase in ADG and feed intake ( } 13.3 \% \text { and } 5.4 \% \text {, respectively) } \\
\text { - Significantly improved in feed conversion ratio }(8.5 \%) \\
\text { - Significant increase in levels of serum thyroid hormones }\left(T_{3} \text { and } T_{4}\right)\end{array}$ & Xu et al [45] \\
\hline Cerium $(C e)$ at 0.5 to $10 \mu \mathrm{mol} / \mathrm{L}$ and $>10 \mu \mathrm{mol} / \mathrm{L}$ & $\begin{array}{l}\text { - Enhanced the activity of } \alpha \text {-amylase from porcine pancreas at lower concentration } \\
(0.5 \text { to } 10 \mu \mathrm{mol} / \mathrm{L}) \\
\text { - Inhibited the activity of } \alpha \text {-amylase at higher concentration of } \mathrm{Ce}^{3+}(>10 \mu \mathrm{mol} / \mathrm{L})\end{array}$ & Wang et al [46] \\
\hline $\begin{array}{l}\text { REE at } 100,200,400 \text {, and } 800 \mathrm{mg} / \mathrm{kg} \text { of DM as } \\
\text { citrate-bound REE (having lanthanum } 30 \text {, cerium } 55 \text {, } \\
\text { praseodymium } 5 \text {, and neodymium } 10 \% \text { ) }\end{array}$ & $\begin{array}{l}\text { - REE supplementation did not disturb the health of animals } \\
\text { - Low concentrations ( } 100 \mathrm{mg} / \mathrm{kg} \mathrm{DM} \text { ) of REE increased weight gain } \\
\text { - Higher concentrations ( } 200 \mathrm{mg} / \mathrm{kg} \text { DM) of REE adversely affected animal growth } \\
\text { performance }\end{array}$ & Förster et al [47] \\
\hline $\begin{array}{l}0.1 \% \text { peptide-bound REE mineral-yeast (mixture } \\
\text { contained } 35.3 \text { lanthanum, } 25.2 \text { cerium, } 10.2 \text { prase- } \\
\text { odymium, and } 29.3 \text { of several minerals which were } \\
\text { present in trace amounts) }\end{array}$ & - Significantly increased in total tract digestibility of DM, CP, and GE & Han and Thacker [48] \\
\hline
\end{tabular}

REE, rare earth elements; $D M$, dry matter; $A D G$, average daily gain; $C P$, crude protein; $G E$, gross energy.

Pr-citrate, $120 \mathrm{~g} / \mathrm{kg}$ ) at $70 \mathrm{mg} / \mathrm{kg}$ in the diet of broiler. It was observed that dietary REE-citrate improved BW gain by $5.0 \%$ while supplementation of REE-chloride showed no improvement as compared to control. In another experiment they supplemented REE-chloride at $70 \mathrm{mg} / \mathrm{kg}$ and REE-citrate at 70 and $100 \mathrm{mg} / \mathrm{kg}$ in the broiler diet. Results showed that only FCR was improved by $3.4 \%$ in group supplemented with REE-citrate at 70 and $100 \mathrm{mg} / \mathrm{kg}$ as compared to RRE chloride and control groups. However, blood serum biochemical parameters were not significantly affected by REE in the diets. From above results it can be assumed that dietary supplementation of REE-citrates at $70 \mathrm{mg} / \mathrm{kg}$ had beneficial effect on growth performance of broilers without affecting carcass composition and health of the broilers. In contrast to above studies, Igbasan and Adebayo [43] observed that supplementation of $\mathrm{La}$ either as $\mathrm{La}$ chloride $\left(\mathrm{LaCl}_{3}\right)$ or $\mathrm{La}$ oxide $\left(\mathrm{La}_{2} \mathrm{O}_{3}\right)$ at $100,200,300$, or $400 \mathrm{mg} / \mathrm{kg} \mathrm{DM}$ in the diet of broiler did not influence growth, carcass quality, haematological and biochemical parameters.

Ruminants: Studies regarding the effect of REE on production performance of ruminants have been summarized in Table 3. REE supplementation in ruminants had variable effect on ADG, feed intake, rumen fermentation and milk production. Literature summarized by Redling [10] reported

Table 2. Literature summary of effect of REE supplementation in poultry

\begin{tabular}{|c|c|c|}
\hline Dose & Results and conclusions & Reference \\
\hline \multirow[t]{4}{*}{$\begin{array}{l}250 \mathrm{mg} / \mathrm{kg} \text { (La } 100 \mathrm{mg} \text {, Ce } 150 \mathrm{mg} \text { ) and } 500 \mathrm{mg} / \mathrm{kg} \\
\text { (La 200, Ce } 300 \mathrm{mg} \text { ) of REE in the diet of laying hen }\end{array}$} & $\begin{array}{l}\text { - Significant increase in plasma Ca and P levels at first and second month } \\
\text { when supplemented group treated with REE at } 250 \mathrm{mg} / \mathrm{kg}\end{array}$ & Reka et al [49] \\
\hline & $\begin{array}{l}\text { - Whereas in group supplemented with } 500 \mathrm{mg} / \mathrm{kg} \text { REE plasma Ca and P } \\
\text { had significantly increased only during first month of the trial }\end{array}$ & \\
\hline & - No significant changes were reported in second month of the trial & \\
\hline & - Non-significant effect on total protein, albumin and globulin level & \\
\hline \multirow{2}{*}{$\begin{array}{l}\text { Lanthanum oxide }\left(\mathrm{La}_{2} \mathrm{O}_{3} ; \text { having } 85.3 \% \mathrm{La}\right) \text { at } 100 \\
(85.3 \mathrm{ppm} \mathrm{La}), 200(171 \mathrm{ppm} \mathrm{La} \text { ) and } 300(256 \mathrm{ppm} \\
\text { La) ppm to starter and finisher diet of broiler }\end{array}$} & $\begin{array}{l}\text { - Improvement in the total weight gain over the control on supplementation } \\
\text { of La at } 171 \mathrm{ppm}\end{array}$ & Agbede et al [50] \\
\hline & $\begin{array}{l}\text { - Relatively lower counts of bacteria were obtained in group supplemented } \\
\text { with } 85.3 \text { ppm La }\end{array}$ & \\
\hline \multirow[t]{2}{*}{$\begin{array}{l}\text { Lanthanum oxide at } 0,100,200,300 \text {, or } 400 \mathrm{mg} / \mathrm{kg} \text { ) } \\
\text { in the diet of laying hen }\end{array}$} & $\begin{array}{l}\text { - Significant increase in Haugh unit and eggshell breaking strength } \\
\text { - Significantly decreased thiobarbituric acid reactive substance (TBARS) } \\
\text { values in egg yolk }\end{array}$ & Durmus and Bolukbası [51] \\
\hline & $\begin{array}{l}\text { - Non-significant effect on SOD and GPx values } \\
\text { - Significant decrease in serum MDA concentration } \\
\text { - Non-significant difference in serum Ca and P level }\end{array}$ & \\
\hline $\begin{array}{l}\text { Cerium oxide at } 0,100,200,300, \text { or } 400 \mathrm{mg} / \mathrm{kg} \text { in } \\
\text { the diet of laying hen }\end{array}$ & $\begin{array}{l}\text { - Non-significant effect on feed intake and egg weight } \\
\text { - Egg production and feed conversion rate were improved by maximum } \\
\text { level of cerium oxide (at } 400 \text { ppm) } \\
\text { - Significant decrease in SOD and MDA concentration } \\
\text { - Significant increase in serum Ca and P concentration }\end{array}$ & Bolukbası et al [52] \\
\hline
\end{tabular}

REE, rare earth elements; SOD, superoxide dismutase; GPx, glutathione peroxidase; MDA, malondialdehyde. 
Table 3. Literature summary of effect of REE supplementation in ruminants

\begin{tabular}{|c|c|c|}
\hline Dose & Results and conclusions & Reference \\
\hline $\begin{array}{l}\text { REE-citrate at 100, 200, and } 300 \mathrm{mg} / \mathrm{kg} \text { DM (having Ce } \\
57.9 \% \text {, La } 34.0 \% \text {, and } \operatorname{Pr} 6.5 \% \text { ) in the diet of fattening } \\
\text { bulls. }\end{array}$ & $\begin{array}{l}\text { - Non-significant effect in feed-to-gain ratio, ME-to-gain ratio and digestibility } \\
\text { of nutrients due supplementation of REE }\end{array}$ & Schwabe et al [7] \\
\hline $\begin{array}{l}\text { REE-citrate at 100, 200, and } 300 \mathrm{mg} / \mathrm{kg} \text { DM (having Ce } \\
57.9 \% \text {, La } 34.0 \% \text {, and } \operatorname{Pr} 6.5 \% \text { ) in the diet of fattening } \\
\text { bulls. }\end{array}$ & $\begin{array}{l}\text { - Significantly linear increase the concentrations of REE (lanthanum [La], cerium } \\
\text { [Ce], and praseodymium [Pr]) in the liver, kidneys and rib bone } \\
\text { - While, the concentration in muscle was not influenced } \\
\text { - Risk to humans from consuming of edible tissue of REE supplemented animals } \\
\text { can be regarded as negligible }\end{array}$ & Schwabe et al [19] \\
\hline $\begin{array}{l}\text { REE-citrate (Ce } 56.8 \% \text {, La } 35.0 \% \text {, and } \operatorname{Pr} 6.5 \% \text { ) at } 100 \text {, } \\
200 \text {, and } 300 \mathrm{mg} / \mathrm{kg} \text { DM in diet of sheep }\end{array}$ & $\begin{array}{l}\text { - Significantly decrease in ruminal pH } \\
\text { - Quadratically decreased in ruminal ammonia content with increasing REE } \\
\text { supplementation } \\
\text { - Other ruminal parameters like total volatile fatty acids concentration and } \\
\text { acetate to propionate ratio were also affected by REE supplementation } \\
\text { - Negative effect on growth of several rumen bacteria } \\
\text { - Digestibility of various nutrients and urinary excretion of purine derivatives } \\
\text { were also increased with increasing REE addition }\end{array}$ & Xun et al [53] \\
\hline $\begin{array}{l}\mathrm{LaCl}_{3}, \mathrm{CeCl}_{3} \text {, or } \mathrm{PrCl}_{3} \text { at } 204 \mathrm{mg} / \mathrm{kg} \mathrm{DM} \text { to the basal } \\
\text { ration of beef cattle }\end{array}$ & $\begin{array}{l}\text { - Linear increase in NDF digestibility and reduced enteric } \mathrm{CH}_{4} \text { emissions } \\
\text { - Significant decreased in total } \mathrm{N} \text { excretion and urinary } \mathrm{N} \text { excretion, increased } \mathrm{N} \\
\text { retention } \\
\text { - Total urinary PD were linearly increase } \\
\text { - Non-significant effect in N retention, urinary PD, microbial N flow and plasma } \\
\text { biochemical parameters }\end{array}$ & Lin et al [54] \\
\hline $\begin{array}{l}\text { Cerium chloride }\left(\mathrm{CeCl}_{3}\right) \text { at } 0,80,160 \text {, and } 240 \mathrm{mg} / \mathrm{kg} \\
\text { DM in beef cattle }\end{array}$ & $\begin{array}{l}\text { - Significant increase in NDF digestibility and } \mathrm{N} \text { retention } \\
\text { - Significantly decreased the molar ratio of rumen acetate to propionate, total } \mathrm{N} \\
\text { excretion, urinary } \mathrm{N} \text { excretion and } \mathrm{CH}_{4} / \mathrm{kg} \mathrm{DMl}\end{array}$ & Lin et al [55] \\
\hline $\begin{array}{l}\text { Lanthanum oxide at } 100,200 \text {, and } 300 \mathrm{mg} / \mathrm{kg} \text { in the } \\
\text { diet of sheep }\end{array}$ & $\begin{array}{l}\text { - Significant improvement in daily weight gain and total weight gain } \\
\text { - Non- significant effect on AST, ALT, cholesterol, urea, total protein, albumin, } \\
\text { and globulin }\end{array}$ & Adu et al [56] \\
\hline $\begin{array}{l}\text { In-vitro addition of REE chloride mixture }\left(\mathrm{LaCl}_{3} 380 \mathrm{mg} /\right. \\
\mathrm{kg} ; \mathrm{CeCl}_{3} 521 \mathrm{mg} / \mathrm{kg}, \mathrm{PrCl}_{3} 30 \mathrm{mg} / \mathrm{kg} \text { and chlorides of } \\
\text { other REE } 69 \mathrm{mg} / \mathrm{kg}) \text { at } 400 \text { and } 800 \mathrm{mg} / \mathrm{kg}\end{array}$ & $\begin{array}{l}\text { - No effect on ruminal VFA concentration } \\
\text { - Impact on VFA profile was marginal } \\
\text { - Linear increase in ruminal true digestibilities of organic acid, acid detergent } \\
\text { fibre and crude protein with increasing REE supplementation }\end{array}$ & Yang et al [34] \\
\hline
\end{tabular}

REE, rare earth elements; ME, metabolizable energy; NDF, neutral detergent fiber; PD, purine derivatives; DMI, day matter intake; AST, aspartate amino transferase; ALT, alanine amino transverse; VFA, volatile fatty acid.

that addition of rare earth oxides (mainly La 22\%, Ce 45\%, and $\mathrm{Nd} 15 \%$ oxides) and rare earth nitrates consisting of (38\%) rare earth oxides $\left(22 \% \mathrm{La}_{2} \mathrm{O}_{3}, 45 \% \mathrm{Ce}_{2} \mathrm{O}_{3}, 15 \% \mathrm{Nd}_{2} \mathrm{O}_{3}\right)$ at 600 and $800 \mathrm{ppm}$ in the diet of fattening cattle and dairy cows improved daily gain and milk production, respectively. Furthermore, Liu et al [33] observed that supplementation of $\mathrm{LaCl}_{3}$ at $900 \mathrm{mg}$ per steer per day significantly $(\mathrm{p}<0.05)$ improved rumen fermentation and feed digestion. Studies revealed that REE supplementation decreased the ruminal $\mathrm{pH}$, which resulted in increased population of cellullytic bacteria, which in turn enhance the digestibility of feed in ruminant. Although, organic form i.e. REE- citrate (REE 25.3\% which contains $57.9 \% \mathrm{Ce}, 34.0 \% \mathrm{La}, 6.5 \% \mathrm{Pr}, 1.6 \%$ of other REE) at $200 \mathrm{mg} / \mathrm{kg} \mathrm{DM}$ in pre-ruminants did not affect feed intake and performance parameters [8]. Similar, reports were reported by Renner et al [17] when they supplemented REEcitrate (containing $34.30 \% \mathrm{La}, 58.09 \% \mathrm{Ce}$, and $7.61 \%$ other REE) up to $300 \mathrm{ppm}$ in growing bulls, however, it was ob- served that the proliferation of peripheral blood mononuclear cells was significantly higher in groups supplemented with REE-citrate at $300 \mathrm{ppm}$, thus REE may play potential role in boosting bovine immune system.

\section{SAFETY ASPECTS OF RARE EARTH ELEMENTS SUPPLEMENTATION TO ANIMALS AND ITS ACCUMULATION IN ANIMAL PRODUCTS}

Results of various studies reported that concentrations of REE in liver and muscle is weakly affected by the dose of REE supplementation in diets of poultry, pig and fattening bull $[21,42,19]$. Moreover, $\mathrm{RE}$ are not highly toxic as $\mathrm{LD}_{50}$ values for IV-injected REE are 10 to $100 \mathrm{mg} / \mathrm{kg} / \mathrm{BW}$ and those of IP-injected REE are 150 to $700 \mathrm{mg} / \mathrm{kg} / \mathrm{BW}$. Toxicity of REE through oral route is very low as only very small amounts of REE are absorbed in the GIT [44]. When rats were given 
higher levels of REE $\left(\mathrm{LaCl}_{3} \cdot 7 \mathrm{H}_{2} \mathrm{O}\right.$ at $1,000 \mathrm{mg} / \mathrm{kg} \mathrm{BW} / \mathrm{d}$ for 28 days) orally, it induced hepatotoxic effect and caused irritation to the stomach mucosa [24]. Hence, it can be supposed that oral supplementation of REE in the diet of animals may pose similar health risk like that of table salt. Further, either due to poor absorption or rapid elimination of REEs from the body of animals the health risks to humans consuming edible tissues from these animals can be regarded as negligible. However, due to limited scientific information there is controversy regarding health benefits and toxic effects of REE on human health [23].

\section{CONCLUSION AND POSSIBLE FUTURE AREAS OF RESEARCH}

After reviewing the complied and cited literature, it is difficult to clarify the biological role of REE on animal performance as there is huge discrepancy among the results of various trials conducted on pig, poultry and ruminants. In case of growing pigs supplementation of REE-chloride mixture up to 1,500 ppm in the diet improved BW gain and FCR by $19 \%$ and $12 \%$, respectively along with higher count of fecal Lactobacillus. However, REE-citrate mixture supplementation up to 800 ppm had no effect on pig performance at all. In case of poultry, REE- citrate mixture supplementation up to $100 \mathrm{ppm}$ in diet of broiler birds improved weight gain and FCR by $5 \%$ and $3.4 \%$, while the supplementation of RRE-chloride mixture showed no effect. Supplementation of REE-chlorides, nitrates, oxide up to $900 \mathrm{ppm}$ and REE-citrate up to $300 \mathrm{ppm}$ in the diet of cattle and sheep respectively, had positive impact on animal performance by improving rumen fermentation and nutrient digestibility. But, REE-citrate supplementation up to $300 \mathrm{ppm}$ had no impact on rumen fermentation and performance of cattle. Apart from above findings, there are few studies which reported that REE had similar impact on fecal micro-biota and growth performance in animals when compared antibiotics supplementation. Moreover, it was also observed that the concentration of REE in various edible tissues was not affected by dose of REE in the diet. Hence, REE might be considered as an alternative to antimicrobial compounds as these are capable of augmenting performance in both ruminants and non-ruminants without any residual effect on edible tissue. Although, there is a need of further research to elucidate the pathways through which REE exerts its action on various physiological processes.

\section{CONFLICT OF INTEREST}

We certify that there is no conflict of interest with any financial organization regarding the material discussed in the manuscript.

\section{ACKNOWLEDGMENTS}

The authors of this paper acknowledge Dr M.S. Mahesh for providing valuable suggestion on this review.

\section{REFERENCES}

1. Tasho RP, Cho JY. Veterinary antibiotics in animal waste, its distribution in soil and uptake by plants: A review. Sci Total Environ 2016;563:366-76. https://doi.org/10.1016/j.scitotenv. 2016.04.140

2. Butaye P, Devriese LA, Haesebrouck F. Antimicrobial growth promoters used in animal feed: effects of less well known antibiotics on gram-positive bacteria. Clin Microbiol Rev 2003;16:175-88. https://doi.org/10.1128/CMR.16.2.175188.2003

3. Landers TF, Cohen B, Wittum TE, Larson EL. A review of antibiotic use in food animals: perspective, policy, and potential. Public Health Rep 2012;127:4-22. https://doi.org/10. 1177/003335491212700103

4. Salyers AA, Gupta A, Wang Y. Human intestinal bacteria as reservoirs for antibiotic resistance genes. Trends Microbiol 2004;12:412-6. https://doi.org/10.1016/j.tim.2004.07.004

5. Mathur S, Singh R. Antibiotic resistance in food lactic acid bacteria-a review. Int J Food Microbiol 2005;105:281-95. https://doi.org/10.1016/j.ijfoodmicro.2005.03.008

6. Devirgiliis C, Zinno P, Perozzi G. Update on antibiotic resistance in foodborne Lactobacillus and Lactococcus species. Front Microbiol 2013;4:301. https://doi.org/10.3389/fmicb. 2013.00301

7. Schwabe A, Meyer U, Flachowsky G, Danicke S. Effect of graded levels of rare earth elements in diets of fattening bulls on growing and slaughtering performance, and on nutrient digestibility of wethers. Arch Anim Nutr 2011;65:55-73. https:// doi.org/10.1080/1745039X.2010.520408

8. Schwabe A, Meyer U, Flachowsky G, Dänicke S. Effects of rare earth elements (REE) supplementation to diets on the health and performance of male and female pre-ruminant calves and growing female calves. vTI Agric For Res 2012;62: 129-36.

9. Wang MQ, Xu ZR. Effect of supplemental lanthanum on the growth performance of pigs. Asian-Australas J Anim Sci 2003; 16:1360-3. https://doi.org/10.5713/ajas.2003.1360

10. Redling K. Rare earth elements in agriculture with emphasis on animal husbandry. München, Germany: Deutsche Veterinärmedizinische Gesellschaft Giessen; 2006.

11. Taylor SR, McLennan SM. The continental crust: its composition and evolution. Oxford, UK: Blackwell; 1985. 312 p.

12.Pal RP, Mani V, Tripathi D, Datt C. Inorganic vanadium supplementation in crossbred calves: effects on antioxidant status, immune response and haemato-biochemical attributes. Biol Trace Elem Res 2018;186:154-61. https://doi.org/10.1007/ 
s12011-018-1295-0

13.Pal RP, Mani V, Tripathi D, Kumar R, Kewalramani NJ. Influence of feeding inorganic vanadium on growth performance, endocrine variables and biomarkers of bone health in crossbred calves. Biol Trace Elem Res 2018;182:248-56. https://doi.org/ 10.1007/s12011-017-1095-y

14. Tripathi D, Mani V, Pal RP. Vanadium in biosphere and its role in biological processes. Biol Trace Elem Res 2018;186:52-67. https://doi.org/10.1007/s12011-018-1289-y

15. Richter H, Schermanz K. Seltene Erden. Rare earths. In: Dittmayer R, Keim W, Kreysa G, Oberholz A, editors. Chemical engineering - processes and products. Weinheim, Germany: Wiley-VCH Verlag; 2006. pp. 147-208.

16. Tyler G. Rare earth elements in soil and plant systems - a review. Plant Soil 2004;267:191-206. https://doi.org/10.1007/s11104005-4888-2

17. Renner L, Schwabe A, Döll S, Höltershinken M, Dänicke S. Effect of rare earth elements on beef cattle growth performance, blood clinical chemical parameters and mitogen stimulated proliferation of bovine peripheral blood mononuclear cells in vitro and ex vivo. Toxicol Lett 2011;201:277-84. https://doi. org/10.1016/j.toxlet.2011.01.014

18. Hirano S, Suzuki KT. Exposure, metabolism, and toxicity of rare earths and related compounds. Environ Health Perspect 1996;104(Suppl 1):85-95. https://doi.org/10.1289/ehp.96104 s185

19.Schwabe A, Meyer U, Grün M, Voigt KD, Flachowsky G, Dänicke S. Effect of rare earth elements (REE) supplementation to diets on the carry-over into different organs and tissues of fattening bulls. Livest Sci 2012;143:5-14. https:// doi.org/10.1016/j.livsci.2011.08.010

20.He ML, Rambeck WA. Rare earth elements a new generation of growth promoters for pigs? Arch Anim Nutr 2000;53:32334. https://doi.org/10.1080/17450390009381956

21.He ML, Ranz D, Rambeck WA. Study on the performance enhancing effect of rare earth elements in growing and fattening pigs. J Anim Physiol Anim Nutr 2001;85:263-70. https:// doi.org/10.1046/j.1439-0396.2001.00327.x

22. Peng L, Yi L, Zhexue L, et al. Study on biological effect of $\mathrm{La}^{3+}$ on Escherichia coli by atomic force microscopy. J Inorganic Biochemis 2004;98:68-72. https://doi.org/10.1016/j.jinorgbio. 2003.08.012

23.Pagano G, Guida M, Tommasi F, Oral R. Health effects and toxicity mechanisms of rare earth elements-Knowledge gaps and research prospects. Ecotoxicol Environ Saf 2015;115:40-8. https://doi.org/10.1016/j.ecoenv.2015.01.030

24. NRC. Mineral tolerance of animals. The 2 nd revised edition. Washington, DC, USA: National Academy Press; 2005.

25. Muroma A. Studies in the bactericidal action of salts of certain rare earth metals, Ann Med Exper et Biol Fenniae 1958;36 (Suppl 6):1-54.

26.Zhang H, Feng J, Zhu W, et al. Chronic toxicity of rare earth elements on human beings: Implications of blood biochemical indexes in REE high regions South Jiangxi. Biol Trace Elem Res 2000;73:1-17. https://doi.org/10.1385/BTER:73:1:1

27.Zhao R, Liu Y, Xie Z, Shen P, Qu S. Microcalorimetric study of the action of $\mathrm{Ce}$ (III) ions on the growth of E. coli. Biol Trace Elem Res 2002;86:167-75.

28. Talburt DE, Johnson GT. Some effects of rare earth elements and yttrium on microbial growth. Mycologia 1967;59:492503. https://doi.org/10.2307/3756768

29. Liu G, Ran Z, Wang H, Liu Y, Shen P, Lu Y. Study on eruption of heat for Escherichia coli B aroused by lanthanum nitrate and its mechanism. Front Chem China 2008;3:70-5. https:// doi.org/10.1007/s11458-008-0010-7

30.Evans $\mathrm{CH}$. Chemical properties of biochemical relevance. In: Biochemistry of the Lanthanides. Biochemistry of the Elements, vol 8. Boston, MA, USA: Springer, 1990. pp. 9-46.

31. Fleckenstein J, Halle I, Hu ZY, Flachowsky G, Schnug E. Analysis of lanthanides using ICP-MS in feed and organ samples in a broiler fattening test. 22nd Workshop on Quantities and Trace Elements, Jena, Germany; 2004. 36 p.

32.Xu X, Xia H, Rui G, Hu C, Yuan F. Effect of lanthanum on secretion of gastric acid in stomach of isolated mice. J Rare Earth 2004;22:427-30.

33.Liu Q, Wang C, Huang YX, Dong KH, Yang WZ, Wang H. Effects of lanthanum on rumen fermentation, urinary excretion of purine derivatives and digestibility in steers. Anim Feed Sci Technol 2008;142:121-32. https://doi.org/10.1016/ j.anifeedsci.2007.08.002

34. Yang WZ, Laarman A, He ML, Liu Q. Effect of rare earth elements on in vitro rumen microbial fermentation and feed digestion. Anim Feed Sci Technol 2009;148:227-40. https:// doi.org/10.1016/j.anifeedsci.2008.03.015

35.He ML, Yang WZ, Mir PS, McAllister TA. Effect of rare earth elements on mitogen-induced proliferation of splenocytes of Wistar rats. Can J Anim Sci 2009;89(Suppl 1):172 (Abstract).

36. Cai L, Nyachoti CM, Kim IH. Impact of rare earth elementenriched yeast on growth performance, nutrient digestibility, blood profile, and fecal microflora in finishing pigs. Can J Anim Sci 2018;98:347-53. https://doi.org/10.1139/cjas-2017-0089

37. Kraatz M, Taras D, Männer K, Simon O. Weaning pig performance and faecal microbiota with and without in-feed addition of rare earth elements. J Anim Physiol Anim Nutr 2006; 90:361-8. https://doi.org/10.1111/j.1439-0396.2005.00594.x

38. Halle I, Böhme H, Schnug E. Investigations on rare earth elements as growth promoting additives in diets for broilers and growing-finishing pigs. In: Kampheus J, Wolf P, editors. Proceedings of the 7th Conference of the European Society of Veterinary and Comparative Nutrition (ESVCN) 2003; Hannover, Germany.

39. Wu J, Zhang Z, Yan J. An inital study on effect of adding rare earth element on productivity of egg laying breeder hens. Ning Xia Sci Technol Farming For 1994;4:36-8. 
40. Fang J, Huang Y, Gong $H$. A study of feeding rare earth elements to black-bone silky fowl. Fujian J Husb Vet 1994;3:28-9.

41. Cai L, Park YS, Seong SI, Yoo SW, Kim IH. Effects of rare earth elements-enriched yeast on growth performance, nutrient digestibility, meat quality, relative organ weight and excreta microflora in broiler chickens. Livest Sci 2015;172:43-9. https:// doi.org/10.1016/j.livsci.2014.11.013

42.He ML, Wehr U, Rambeck WA. Effect of low doses of dietary rare earth elements on growth performance of broilers. J Anim Physiol Anim Nutr 2010;94:86-92. https://doi.org/10.1111/ j.1439-0396.2008.00884.x

43. Igbasan FA, Adebayo OS. Growth response, carcass quality, some haematological and biochemical parameters of broiler chickens fed on diets supplemented with lanthanum salts. Int J Sci Eng Res 2012;3:1-17.

44. Damment SJP, Pennick M. Systemic lanthanum is excreted in the bile of rats. Toxicol Lett 2007;171:69-77. https://doi. org/10.1016/j.toxlet.2007.04.005

45.Xu Z, Wang M, Chen L. Growth response of pigs fed supplemental lanthanum and approach of mechanism. J Chin Rare Earth Soc 1999;17:53-9.

46. Wang X, Hong F, Shen S. Effect of cerium on activity of a amylase from porcine pancreas. J Chin Rare Earth Soc 2002;20: 353-6.

47. Forster D, Berk A, Hoppen HO, Rambeck WA, Flachowsky G. A note on the effect of rare earth elements on the performance and thyroid hormone status of rearing piglets. J Anim Feed Sci 2008;17:70-4. https://doi.org/10.22358/jafs/66471/ 2008

48.Han YK, Thacker PA. Effects of antibiotics, zinc oxide or a rare earth mineral-yeast product on performance, nutrient digestibility and serum parameters in weanling pigs. AsianAustralas J Anim Sci 2010;23:1057-65. https://doi.org/10.5713/ ajas.2010.90569

49. Reka D, Thavasiappan V, Selvaraj P, Arivuchelvan A. Effect of dietary REE supplementation on blood biochemical parameters in layer chicken. Int J Curr Microbiol App Sci 2018; 7:181-5. https://doi.org/10.20546/ijcmas.2018.701.020

50.Agbede, JO, Arimah AA, Adu OA, Olaleye MT, Aletor VA. Growth-enhancing, health impact and bacteria suppressive property of lanthanum supplementation in broiler chicken. Archiva Zootechnica 2011;14:44-56.

51.Durmuş O, Bölükbaşı ŞC. Biological activities of lanthanum oxide in laying hens. J Appl Poult Res 2015;24:481-8. https:// doi.org/10.3382/japr/pfv052

52. Bölükbaşı SC, Al-sagan AA, Ürüşan H, Erhan MK, Durmuş O, Kurt N. Effects of cerium oxide supplementation to laying hen diets on performance, egg quality, some antioxidant enzymes in serum and lipid oxidation in egg yolk. J Anim Physiol Anim Nutr 2016;100:686-93. https://doi.org/10.1111/ jpn.12429

53.Xun W, Shi L, Hou G, et al. Effect of rare earth elements on feed digestibility, rumen fermentation, and purine derivatives in sheep. Italian J Anim Sci 2014;13:3205. https://doi.org/10. 4081/ijas.2014.3205

54.Lin S, Wei C, Zhao G, Zhang T, Yang K. Comparison of the effects of lanthanum, cerium and praseodymium on rumen fermentation, nutrient digestion and plasma biochemical parameters in beef cattle. Arch Anim Nutr 2015;69:46-56. https://doi.org/10.1080/1745039X.2014.998458

55.Lin SX, Wei C, Zhao GY, Zhang TT, Yang K. Effects of supplementing rare earth element cerium on rumen fermentation, nutrient digestibility, nitrogen balance and plasma biochemical parameters in beef cattle. J Anim Physiol Anim Nutr 2015; 99:1047-55. https://doi.org/10.1111/jpn.12295

56. Adu OA, Adeseye SA, Adebiyi OA, Olumide MD, Igbasan FA, Alokan JA. Performance of West African dwarf sheep fed diets supplemented with rare earth elements (REE). J Agric For Soc Sci 2006;4:166-74. 